OPEN ACCESS

Edited by:

Subhash C. Verma, University of Nevada, Reno, United States

Reviewed by: Juliet Spencer, Texas Woman's University, United States

Neelam Sharma-Walia, Rosalind Franklin University of Medicine and Science, United States

*Correspondence: Christian Münz christian.muenz@uzh.ch

Specialty section: This article was submitted to Virus and Host,

a section of the journal Frontiers in Cellular and Infection Microbiology

Received: 11 September 2020 Accepted: 09 March 2021 Published: 26 March 2021

Citation: Münz C (2021) The Role of Lytic Infection for Lymphomagenesis of Human $\gamma$-Herpesviruses. Front. Cell. Infect. Microbiol. 11:605258. doi: 10.3389/fcimb.2021.605258

\section{The Role of Lytic Infection for Lymphomagenesis of Human $\gamma$-Herpesviruses}

\author{
Christian Münz * \\ Viral Immunobiology, Institute of Experimental Immunology, University of Zürich, Zürich, Switzerland
}

Epstein Barr virus (EBV) and Kaposi sarcoma associated herpesvirus (KSHV) are two oncogenic human $\gamma$-herpesviruses that are each associated with $1-2 \%$ of human tumors. They encode bona fide oncogenes that they express during latent infection to amplify their host cells and themselves within these. In contrast, lytic virus particle producing infection has been considered to destroy host cells and might be even induced to therapeutically eliminate EBV and KSHV associated tumors. However, it has become apparent in recent years that early lytic replication supports tumorigenesis by these two human oncogenic viruses. This review will discuss the evidence for this paradigm change and how lytic gene products might condition the microenvironment to facilitate EBV and KSHV associated tumorigenesis.

Keywords: Epstein Barr virus, Kaposi sarcoma associated herpesvirus, viral IL-10, viral IL-6, viral G-protein coupled receptor, early lytic EBV antigen specific T cells, natural killer cells

\section{INTRODUCTION ON EBV AND KSHV INFECTION AND TUMORIGENESIS}

Epstein Barr virus (EBV) and Kaposi sarcoma associated herpesvirus (KSHV) are the two human $\gamma$ herpesviruses (human herpesvirus 4 and 8, respectively) (Ehlers et al., 2010). Both are quite successful pathogens in the human population and have no other known animal hosts (Münz, 2019; Cesarman et al., 2019). EBV persistently infects more than $95 \%$ of the human adult population, and while rare in the Northern hemisphere, persistent KSHV infection is found in more than $50 \%$ of individuals in subSaharan Africa. Both viruses encode latent and lytic gene products (Mariggio et al., 2017; Frost and Gewurz, 2018). While lytic replication allows through the expression of immediate early, early and late structural $\gamma$-herpesvirus genes the production of infectious viral particles, latent gene expression is thought to maintain viral DNA in proliferating lymphocytes, probably primarily B cells, rescue them from apoptosis and drive them into differentiation to long-lived memory cells for persistence (ThorleyLawson, 2001; Dittmer and Damania, 2016; Frohlich and Grundhoff, 2020). For this purpose, EBV encodes six latent nuclear (EBNA1, 2, 3A, 3B, 3C and LP), two latent membrane (LMP1 and 2) and non-translated RNAs (Epstein-Barr virus-encoded small RNAs or EBERs and miRNAs) (Kempkes and Robertson, 2015). They are grouped in four latency patterns (0, I, II and III). Latency III expresses all latency genes and can be found in naïve B cells of healthy virus carriers, latency II only EBNA1, LMP1 and 2 plus non-translated RNAs in germinal center B cells, latency I only EBNA1 at the protein level in homeostatically proliferating memory $\mathrm{B}$ cells and latency 0 only non-translated RNAs in resting memory B cells as the site of EBV persistence (Babcock et al., 2000; Hochberg et al., 2004). KSHV expresses latency-associated nuclear antigen (LANA), vCyclin, viral FADD-like interleukin-1-betaconverting enzyme [FLICE/caspase 8]-inhibitory protein (vFlip), Kaposins and non-translated RNAs 
(miRNAs) during latency (Frohlich and Grundhoff, 2020). However, lytic KSHV gene products are often co-expressed even in poorly infectious virus-producing cells, and KSHV latency has not yet been linked to a human B cell differentiation program.

Nevertheless, latent EBV and KSHV gene products have oncogenic abilities and, therefore, both human $\gamma$-herpesviruses are designated WHO class I carcinogens (Parkin, 2006; Bouvard et al., 2009). Although EBV encodes the more potent growth transforming gene products (Kulwichit et al., 1998; Sin and Dittmer, 2013; Sin et al., 2015; AlQarni et al., 2018) and can readily immortalize human B cells in vitro (Pich et al., 2019), each of the two viruses is associated with around 1$2 \%$ of all cancers in humans (Cesarman, 2014; Cesarman et al., 2019; Shannon-Lowe and Rickinson, 2019). These include primarily B cell lymphomas and epithelial cell carcinomas for EBV, and endothelial cell cancers and B cell lymphoproliferations for KSHV. EBV latency I is present in Burkitt's lymphoma, latency II in Hodgkin's lymphoma and nasopharyngeal carcinoma, and latency III in some diffuse large B cell lymphomas (DLBCL) and post-transplant lymphoproliferative disease (PTLD) (Shannon-Lowe and Rickinson, 2019). KSHV is associated with the endothelial cell tumor Kaposi sarcoma and multicentric Castleman's disease (Cesarman, 2014; Cesarman et al., 2019). Finally, primary effusion lymphoma (PEL), a plasmacytoma (Klein et al., 2003), is to $100 \%$ associated with KSHV and harbors in addition EBV in 90\% of cases (Cesarman et al., 1995; Nador et al., 1996; Cesarman, 2011). Interestingly, it is also the only KSHV associated tumor, from which readily transformed cell lines can be established in vitro that maintain KSHV (Frohlich and Grundhoff, 2020). Interestingly, co-infection with EBV allows KSHV persistence in mice with reconstituted human immune system components (humanized mice), and results in PEL-like lymphomagenesis (McHugh et al., 2017). Similarly, the two $\gamma$-herpesviruses or their monkey orthologues seem to be also co-transmitted in Cameroonian children and macaques (Bruce et al., 2018; Labo et al., 2019). EBV seropositivity was also found to be the strongest correlate of KSHV seropositivity in a rural Ugandan patient cohort (Sallah et al., 2020). Finally, EBV supports KSHV persistence after primary B cell infection and improves KSHV DNA maintenance after infection of EBV negative PEL in vitro (Bigi et al., 2018; Faure et al., 2019). Thus, KSHV might rely on EBV for its persistence, bidirectionally influencing their viral gene expression. I will primarily focus in this review on this interaction of EBV and KSHV in associated lymphomas.

\section{CONTRIBUTION OF LYTIC $\gamma$-HERPESVIRUS INFECTION TO LYMPHOMAGENESIS}

One facet of how these two tumor viruses influence each other is that KSHV induces lytic EBV replication (McHugh et al., 2017). This is observed in double-infected B cells of humanized mice and double-infected PELs of patients. Surprisingly, this increased lytic EBV infection contributes also to the more frequent lymphomagenesis that is observed in KSHV and EBV infected humanized mice, because co-infection with lytic replication deficient EBV lacking the immediate early lytic activator BZLF1 (BamH1 Z fragment encoding leftward reading frame 1) does not cause more tumors than EBV single infection (McHugh et al., 2017). Similarly, BZLF1 deficient EBV infection was reported to cause fewer lymphomas than wild-type EBV infection in a smaller percentage of humanized mice (Ma et al., 2011; Antsiferova et al., 2014). This effect seemed more pronounced for lymphoma dissemination to liver and kidney than in spleen (Antsiferova et al., 2014). Vice versa, BZLF1 promotor variants that increase lytic EBV replication promote lymphomagenesis in humanized mice (Ma et al., 2012; Bristol et al., 2018). This was shown for a triple mutant (ZV,ZV' and ZIIR) and the nasopharyngeal carcinoma associated V3 variant of the BZLF1 promotor. Decreased lymphomagenesis in the absence of lytic EBV replication is somewhat counterintuitive because infectious particle production is thought to lead to infected cell death, counteracting tumor cell proliferation.

Increased tumor formation in the presence of lytic EBV replication is, however, not only observed in humanized mice. Viruses that are enriched in EBV associated NK/T cell lymphomas and DLBCLs frequently carry deletions in the BART (BamH1 A fragment encoding rightward transcripts) miRNA encoding region that is thought to suppress lytic EBV replication by targeting expression of BZLF1 and the other lytic transactivator BRLF1 (Okuno et al., 2019). Moreover, plasma rather than cell-associated viral loads seems to be predictive of EBV associated tumorigenesis, such as nasopharyngeal carcinoma, PTLD, DLBCL, NK/T cell lymphoma and Hodgkin's lymphoma, suggesting that lytic EBV replication is associated with these EBV associated malignancies (Kanakry et al., 2016).

How might such lytic EBV replication support tumor formation? It is likely that abortive early lytic EBV infection plays a pro-tumorigenic role (Münz, 2019). Accordingly, B cells transformed with a mutant EBV lacking the late lytic gene product BALF5 were more efficient in establishing lymphomas in immune compromised mice (Okuno et al., 2019). The pro-lymphomagenic effects of early lytic EBV gene products could be in part mediated by shaping the tumor microenvironment. Along these lines EBV transformed B cells with higher spontaneous lytic reactivation produce more tumour necrosis factor (TNF), CCL5 (RANTES) and IL-10 (Arvey et al., 2015) (Figure 1). In addition, EBV encodes also viral IL-10 (BCRF1) (Jochum et al., 2012). These could promote an immune suppressive tumor microenvironment through vIL-10 and IL-10 mediated T cell response suppression, as well as CCL5 dependent recruitment of myeloid suppressor cells (Casagrande et al., 2019; Walens et al., 2019). Similarly, early lytic KSHV gene products might promote lymphomagenesis (Figure 1). Along these lines viral IL-6 (ORF-K2) supports B cell lymphoma dissemination in immune compromised mice and $\mathrm{B}$ cell hyperproliferation in transgenic mice (Suthaus et al., 2012; Fullwood et al., 2018). Together with cMyc overexpression it can also support lymphoma formation in mice (Rosean et al., 2016). Thus, viral IL-6 probably serves as an auto- and paracrine growth factor for KSHV infected B cells. Furthermore, transgenic expression of viral protein kinase of KSHV (ORF36) in mice leads to B cell hyperproliferation and lymphoma development at increased frequency, compared to littermate mice (Anders et al., 2018). Viral protein kinase seems to facilitate $\mathrm{B}$ cell activation during KSHV infection. Moreover, also K1 transgenic mice develop lymphoproliferations and lymphomas in half of the animals (Prakash et al., 2000; Prakash et al., 2002; Prakash et al., 2005; 


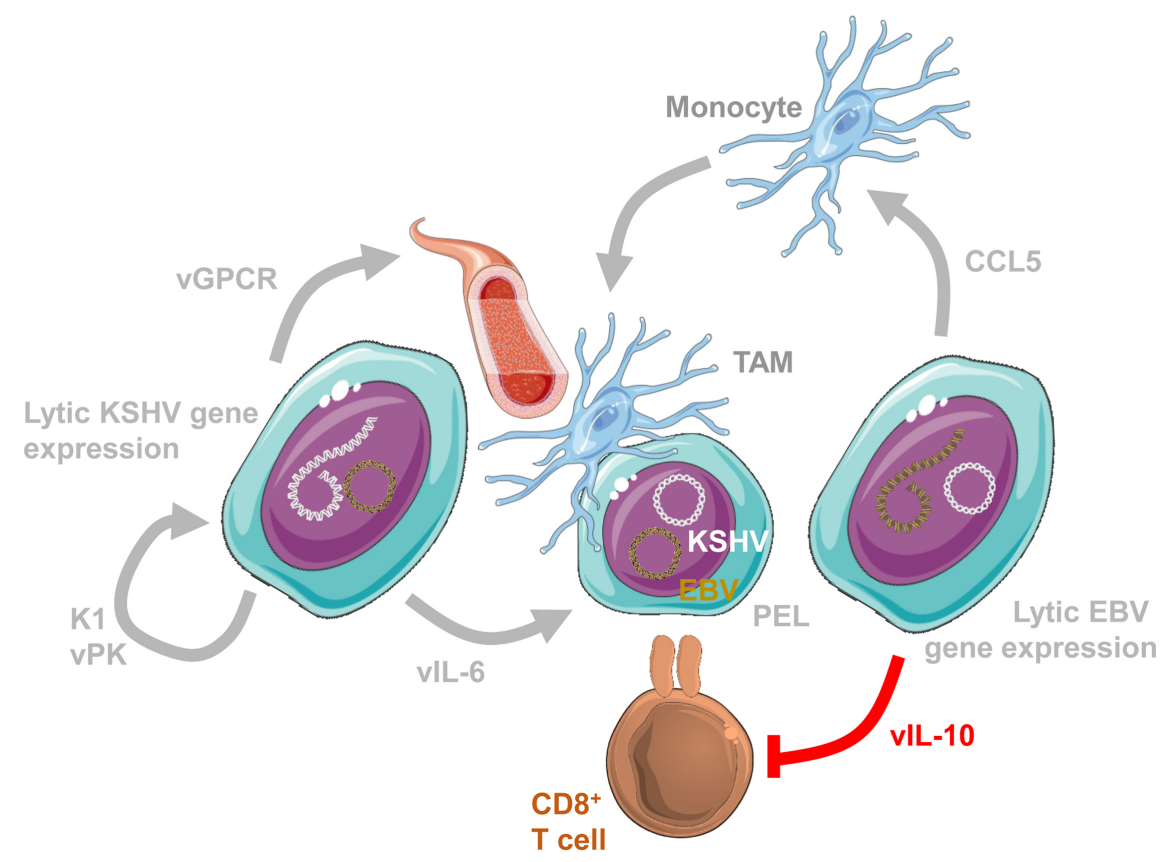

FIGURE 1 | Lytic EBV and KSHV gene expression condition the tumor microenvironment. Conditioning of the tumor microenvironment by Iytic EBV and KSHV gene products occurs most likely at the same time in primary effusion lymphomas (PELs) that are 100\% KSHV and 90\% EBV infected. Lytic EBV replication attracts monocytes via CCL5 to become immune suppressive tumor associated macrophages (TAMs). Viral IL-10 (vlL-10; BCRF1) suppresses CD8 ${ }^{+}$T cell recognition. In addition, the lytic KSHV product viral G-protein coupled receptor (vGPCR; ORF74) promotes angiogenesis. Furthermore, K1 (ORF-K1) and viral protein kinase (VPK; ORF36) promote proliferation of KSHV infected cells. Finally, viral IL-6 (vlL-6; ORF-K2) promotes KSHV infected B cell proliferation. This figure was created in part with modified Servier Medical Art templates, which are licensed under a Creative Commons Attribution 3.0 unported license: https://smart.servier.com.

Wang et al., 2007; Berkova et al., 2015). K1 encodes an activating receptor that promotes $\mathrm{B}$ cell stimulation and apoptosis resistance, including inhibition of Fas mediated extrinsic cell death induction. Finally, inducible expression of viral G protein-coupled receptor (ORF74) promotes angiogenesis and thereby Kaposi sarcoma-like tumorigenesis in mice (Yang et al., 2000; Holst et al., 2001; Guo et al., 2003; Montaner et al., 2003; Montaner et al., 2004; Jensen et al., 2005; Grisotto et al., 2006). Thus, early lytic gene products of both EBV and KSHV might condition the tumor microenvironment for more efficient malignancy development.

\section{PROTECTION FROM TUMORIGENESIS BY LYTIC $\gamma$-HERPESVIRUS REPLICATION SPECIFIC IMMUNE RESPONSES}

In addition to this evidence from infections with mutant or variant $\gamma$-herpesviruses and early lytic viral gene product overexpression, protection by lytic replication specific immune responses against EBV and KSHV associated tumors points towards the importance of lytic infection in virus-associated malignancies. Uncontrolled lytic EBV replication might cause symptomatic primary EBV infection, called infectious mononucleosis (IM) (Luzuriaga and Sullivan, 2010). While two thirds of Europeans and Northern Americans acquire EBV prior to the age of two, the remaining one third often gets infected in the second decade of life (Dunmire et al., 2018). One third to half of these developed a strong $\mathrm{CD}^{+} \mathrm{T}$ cell lymphocytosis four to six weeks after EBV encounter. They shed infectious virus at increased titers into saliva often for months, develop antibodies against structural proteins like viral capsid antigen (VCA), but not yet EBNA1, and the majority of the expanding $\mathrm{CD}^{+} \mathrm{T}$ cells are directed against early lytic EBV antigens with individual peptide specificities constituting up to $40 \%$ of the total $\mathrm{CD}^{+} \mathrm{T}$ cell compartment (Callan et al., 1998). In contrast, latent EBV antigen specific $\mathrm{CD}^{+}{ }^{+} \mathrm{T}$ cells emerge at IM convalescence and were therefore proposed to be the protective entity of EBV specific immune responses (Taylor et al., 2015). IM increases the risk to develop EBV associated Hodgkin's lymphoma 4 fold, but only for around 5 years after primary EBV infection (Hjalgrim et al., 2003). This was characterized in more than 50'000 adolescents and young adults in Scandinavian countries, as well as several follow-up studies (Hjalgrim et al., 2007; Hjalgrim et al., 2010). Therefore, uncontrolled lytic EBV replication could predispose for some EBV associated lymphomas.

Along with $\mathrm{CD}^{+} \mathrm{T}$ cells, natural killer (NK) cells expand during IM (Williams et al., 2005; Balfour et al., 2013; Azzi et al., 2014). Primarily, early differentiated NK cells expressing inhibitory NKG2A but not killer immunoglobulin-like receptors (KIRs) expand around 4fold (Azzi et al., 2014; Hendricks et al., 2014). These degranulate their cytotoxic molecules preferentially in the presence of lytically EBV replicating B cells (Chijioke et al., 2013; Azzi et al., 2014). Accordingly, NK cells of humanized mice which are also enriched in this early differentiated NK cell phenotype (Strowig et al., 2010) restrict wild-type but not BZLF1 deficient EBV 
infection (Chijioke et al., 2013; Landtwing et al., 2016). Restriction of lytic EBV replication by NK cells also reduced lymphoma formation, because NKp46 directed antibody depletion of NK cells leads to higher frequencies of DLBCL-like lymphomas in humanized mice (Chijioke et al., 2013; Landtwing et al., 2016).

Recognition of lytically EBV replicating B cells by NK cells seems to be primarily mediated via recognition by natural killer group 2 member D (NKG2D) with DNAX accessory molecule 1 (DNAM-1) as co-receptor (Pappworth et al., 2007). Their ligands are upregulated on $\mathrm{B}$ cells upon induction of lytic EBV infection (Pappworth et al., 2007). NKG2D surface expression on NK and $\mathrm{CD}^{+} \mathrm{T}$ cells is reduced due to inefficient glycosylation by loss-offunction mutations in the $\mathrm{Mg}^{2+}$ transporter MAGT1 in patients with X-linked immunodeficiency with magnesium defect, EpsteinBarr virus (EBV) infection, and neoplasia (XMEN) (ChaigneDelalande et al., 2013; Dhalla et al., 2015; Patiroglu et al., 2015; Brigida et al., 2017; Ravell et al., 2020a). EBV associated lymphomas develop in one third of the affected patients, but interestingly also one patient with Kaposi sarcoma was reported (Brigida et al., 2017; Ravell et al., 2020b). $\mathrm{Mg}^{2+}$ supplementation can restore NKG2D surface expression and EBV specific immune control in some of these patients (Chaigne-Delalande et al., 2013), but has not proven to be a successful durable therapy of XMEN (Ravell et al., 2020b). Nevertheless, NKG2D recognition of lytically replicating EBV infected B cells seems to be essential to prevent lymphomas.

In addition, the other primary immunodeficiencies that predispose for EBV associated diseases also seem to point towards cytotoxic lymphocytes, including $\mathrm{NK}$ and $\mathrm{CD}^{+} \mathrm{T}$ cells, as main components of EBV specific immune control (Damania and Münz, 2019; Latour and Fischer, 2019; Tangye and Latour, 2020). These affect the cytotoxic machinery (perforin, Munc13-4, Munc18-2), T cell receptor signaling (ITK, PI3K, RasGRP1, ZAP70, CORO1A), co-stimulation (CD27, CD70, 4-1BB, CTLA4, SAP) as well as cytotoxic lymphocyte development and expansion (GATA2, MCM4, XIAP, STK4, CTPS1). While EBV specific immune control seems to be independent of type I and II interferons (IFNs) and antibodies (Latour and Fischer, 2019; Münz, 2020), type II IFN signaling seems to be required for KSHV specific immune control, and is compromised by mutations in IFN $\gamma R 1$ and STAT4 (Damania and Münz, 2019). Furthermore, the requirements for co-stimulation seem to be different with OX40 being essential for KSHV specific immune control (Byun et al., 2013). Nevertheless, T cells rather than B cells seem to be important for the immune control of both $\gamma$-herpesviruses.

Among these, adoptive transfer of early lytic EBV antigen specific $\mathrm{CD}^{+} \mathrm{T}$ cells has been shown to transiently control EBV infection in humanized mice (Antsiferova et al., 2014). Furthermore, late lytic EBV antigen specific $\mathrm{CD} 4{ }^{+} \mathrm{T}$ cells have been demonstrated to control EBV transformed B cells in immune compromised mice (Linnerbauer et al., 2014). Both of these T cell specificities display cytotoxicity against EBV transformed B cell lines (Heller et al., 2006). Early lytic EBV antigen specific $\mathrm{CD}^{+} \mathrm{T}$ cell responses are also maintained at higher frequency than latent and late lytic antigen specific responses (Abbott et al., 2013). Similarly, KSHV lytic antigens are also more frequently recognized by $\mathrm{CD}^{+}$and $\mathrm{CD} 8^{+} \mathrm{T}$ cells (Robey et al., 2010; Roshan et al., 2017). Their protective functions against KSHV infected cells and in humanized mice need to be characterized in more detail in the future.

\section{CONCLUSIONS}

Recent evidence suggests that most likely abortive early lytic replication in many cells or productive lytic replication in a few cells promotes KSHV and EBV associated lymphoma formation (Münz, 2019). In healthy virus carriers a large proportion of the cytotoxic $\mathrm{CD}^{+} \mathrm{T}$ cell response is dedicated to the recognition of early lytic KSHV and EBV antigens, probably more than to their latent antigens (Long et al., 2019). In contrast, most EBV specific vaccination approaches have so far focused on latent antigens to elicit protective $\mathrm{T}$ cells and late lytic antigens to induce antibodies (Taylor et al., 2004; Smith et al., 2006; Moutschen et al., 2007; Gurer et al., 2008; Ruiss et al., 2011; Meixlsperger et al., 2013; Kanekiyo et al., 2015; van Zyl et al., 2018; Rühl et al., 2019; Bu et al., 2019). From these studies the latent EBV antigens EBNA1, LMP1 and LMP2 have emerged as protective antigens (Rühl et al., 2020). In humanized mice, EBNA1 incorporated into an EBV derived virus-like particle (VLP), but not the VLP itself protected from challenge by EBV infection (van Zyl et al., 2018). In contrast to the B cell trophic VLP, EBNA1 targeting to dendritic cells (DCs) with recombinant antibodies and a potent adjuvant to activate classical DCs was not able to elicit sufficient $\mathrm{T}$ cell responses for protection (Gurer et al., 2008; Meixlsperger et al., 2013), even so both vaccines elicited primarily cytotoxic $\mathrm{CD}^{+} \mathrm{T}$ cell responses (Meixlsperger et al., 2013; van Zyl et al., 2018). Recombinant viral vectors are more efficient in eliciting $\mathrm{CD}^{+} \mathrm{T}$ cell responses and they can be combined with $\mathrm{CD}^{+} \mathrm{T}$ cell eliciting vaccines in heterologous protective vaccination (Rühl et al., 2019). For such comprehensively CD4 ${ }^{+}$ and $\mathrm{CD}^{+} \mathrm{T}$ cell eliciting vaccines incorporation of early lytic EBV antigens, like BMLF1 (Antsiferova et al., 2014) should be considered. If proving efficient such vaccine formulations could then also be extended to lytic KSHV antigens. Thus, the new appreciation of a contribution of early lytic replication to possibly both EBV and KSHV associated tumorigenesis gives us also additional antigens that could be explored for vaccination against these two human tumor viruses.

\section{AUTHOR CONTRIBUTIONS}

The author confirms being the sole contributor of this work and has approved it for publication.

\section{FUNDING}

Research in my laboratory is supported by Cancer Research Switzerland (KFS-4091-02-2017 and KFS-4962-02-2020), KFSPPrecision $^{\mathrm{MS}}$ and HMZ ImmunoTargET of the University of Zurich, the Cancer Research Center Zurich, the Baugarten Foundation, the Sobek Foundation, the Swiss Vaccine Research Institute, Roche, Novartis and the Swiss National Science Foundation (310030B_182827 and CRSII5_180323). The funders were not involved in the study design, collection, analysis, interpretation of data, the writing of this article or the decision to submit it for publication. 


\section{REFERENCES}

Abbott, R. J., Quinn, L. L., Leese, A. M., Scholes, H. M., Pachnio, A., and Rickinson, A. B. (2013). $\mathrm{CD}^{+} \mathrm{T}$ cell responses to lytic EBV infection: late antigen specificities as subdominant components of the total response. J. Immunol. 191, 5398-5409. doi: 10.4049/jimmunol.1301629

AlQarni, S., Al-Sheikh, Y., Campbell, D., Drotar, M., Hannigan, A., Boyle, S., et al. (2018). Lymphomas driven by Epstein-Barr virus nuclear antigen-1 (EBNA1) are dependant upon Mdm2. Oncogene. 37, 3998-4012. doi: 10.1038/s41388018-0147-x

Anders, P. M., Montgomery, N. D., Montgomery, S. A., Bhatt, A. P., Dittmer, D. P., and Damania, B. (2018). Human herpesvirus-encoded kinase induces B cell lymphomas in vivo. J. Clin. Invest. 128, 2519-2534. doi: 10.1172/JCI97053

Antsiferova, O., Müller, A., Rämer, P., Chijioke, O., Chatterjee, B., Raykova, A., et al. (2014). Adoptive transfer of EBV specific $\mathrm{CD}^{+} \mathrm{T}$ cell clones can transiently control EBV infection in humanized mice. PloS Pathog. 10, e1004333. doi: 10.1371/journal.ppat.1004333

Arvey, A., Ojesina, A. I., Pedamallu, C. S., Ballon, G., Jung, J., Duke, F., et al. (2015). The tumor virus landscape of AIDS-related lymphomas. Blood 125, e14-e22. doi: 10.1182/blood-2014-11-599951

Azzi, T., Lunemann, A., Murer, A., Ueda, S., Beziat, V., Malmberg, K. J., et al. (2014). Role for early-differentiated natural killer cells in infectious mononucleosis. Blood 124, 2533-2543. doi: 10.1182/blood-2014-01-553024

Babcock, J. G., Hochberg, D., and Thorley-Lawson, A. D. (2000). The expression pattern of Epstein-Barr virus latent genes in vivo is dependent upon the differentiation stage of the infected B cell. Immunity 13, 497-506. doi: 10.1016/ S1074-7613(00)00049-2

Balfour, H. H.Jr., Odumade, O. A., Schmeling, D. O., Mullan, B. D., Ed, J. A., Knight, J. A., et al. (2013). Behavioral, virologic, and immunologic factors associated with acquisition and severity of primary epstein-barr virus infection in university students. J. Infect. Dis. 207, 80-88. doi: 10.1093/infdis/jis646

Berkova, Z., Wang, S., Sehgal, L., Patel, K. P., Prakash, O., and Samaniego, F. (2015). Lymphoid hyperplasia and lymphoma in KSHV K1 transgenic mice. Histol. Histopathol. 30, 559-568. doi: 10.14670/HH-30.559

Bigi, R., Landis, J. T., An, H., Caro-Vegas, C., Raab-Traub, N., and Dittmer, D. P. (2018). Epstein-Barr virus enhances genome maintenance of Kaposi sarcomaassociated herpesvirus. Proc. Natl. Acad. Sci. U.S.A. 115, E11379-E11387. doi: 10.1073/pnas.1810128115

Bouvard, V., Baan, R., Straif, K., Grosse, Y., Secretan, B., El Ghissassi, F., et al. (2009). A review of human carcinogens-Part B: biological agents. Lancet Oncol. 10, 321-322. doi: 10.1016/S1470-2045(09)70096-8

Brigida, I., Chiriaco, M., Di Cesare, S., Cittaro, D., Di Matteo, G., Giannelli, S., et al. (2017). Large Deletion of MAGT1 Gene in a Patient with Classic Kaposi Sarcoma, CD4 Lymphopenia, and EBV Infection. J. Clin. Immunol. 37, 32-35. doi: 10.1007/s10875-016-0341-y

Bristol, J. A., Djavadian, R., Albright, E. R., Coleman, C. B., Ohashi, M., Hayes, M., et al. (2018). A cancer-associated Epstein-Barr virus BZLF1 promoter variant enhances lytic infection. PloS Pathog. 14, e1007179. doi: 10.1371/journal.ppat.1007179

Bruce, A. G., Barcy, S., Staheli, J., Bielefeldt-Ohmann, H., Ikoma, M., Howard, K., et al. (2018). Experimental co-transmission of Simian Immunodeficiency Virus (SIV) and the macaque homologs of the Kaposi Sarcoma-Associated Herpesvirus (KSHV) and Epstein-Barr Virus (EBV). PloS One 13, e0205632. doi: 10.1371/journal.pone.0205632

Bu, W., Joyce, M. G., Nguyen, H., Banh, D. V., Aguilar, F., Tariq, Z., et al. (2019). Immunization with Components of the Viral Fusion Apparatus Elicits Antibodies That Neutralize Epstein-Barr Virus in B Cells and Epithelial Cells. Immunity 50, 1305-1316 e6. doi: 10.1016/j.immuni.2019.03.010

Byun, M., Ma, C. S., Akcay, A., Pedergnana, V., Palendira, U., Myoung, J., et al. (2013). Inherited human OX40 deficiency underlying classic Kaposi sarcoma of childhood. J. Exp. Med. 210, 1743-1759. doi: 10.1084/jem.20130592

Callan, M. F., Tan, L., Annels, N., Ogg, G. S., Wilson, J. D., O'Callaghan, C. A., et al. (1998). Direct visualization of antigen-specific $\mathrm{CD}^{+} \mathrm{T}$ cells during the primary immune response to Epstein-Barr virus In vivo. J. Exp. Med. 187, 1395-1402. doi: 10.1084/jem.187.9.1395

Casagrande, N., Borghese, C., Visser, L., Mongiat, M., Colombatti, A., and Aldinucci, D. (2019). CCR5 antagonism by maraviroc inhibits Hodgkin lymphoma microenvironment interactions and xenograft growth. Haematologica 104, 564-575. doi: 10.3324/haematol.2018.196725
Cesarman, E., Chang, Y., Moore, P. S., Said, J. W., and Knowles, D. M. (1995). Kaposi's sarcoma-associated herpesvirus-like DNA sequences in AIDS-related body-cavity-based lymphomas. N. Engl. J. Med. 332, 1186-1191. doi: 10.1056/ NEJM199505043321802

Cesarman, E., Damania, B., Krown, S. E., Martin, J., Bower, M., and Whitby, D. (2019). Kaposi sarcoma. Nat. Rev. Dis. Primers 5, 9. doi: 10.1038/s41572-0190060-9

Cesarman, E. (2011). Gammaherpesvirus and lymphoproliferative disorders in immunocompromised patients. Cancer Lett. 305, 163-174. doi: 10.1016/ j.canlet.2011.03.003

Cesarman, E. (2014). Gammaherpesviruses and lymphoproliferative disorders. Annu. Rev. Pathol. 9, 349-372. doi: 10.1146/annurev-pathol-012513-104656

Chaigne-Delalande, B., Li, F. Y., O'Connor, G. M., Lukacs, M. J., Jiang, P., Zheng, L. et al. (2013). $\mathrm{Mg}^{2+}$ regulates cytotoxic functions of NK and CD8 $\mathrm{T}$ cells in chronic EBV infection through NKG2D. Science 341, 186-191. doi: 10.1126/ science. 1240094

Chijioke, O., Muller, A., Feederle, R., Barros, M. H., Krieg, C., Emmel, V., et al. (2013). Human natural killer cells prevent infectious mononucleosis features by targeting lytic Epstein-Barr virus infection. Cell Rep. 5, 1489-1498. doi: 10.1016/j.celrep.2013.11.041

Damania, B., and Münz, C. (2019). Immunodeficiencies that predispose to pathologies by human oncogenic gamma-herpesviruses. FEMS Microbiol. Rev. 43, 181-192. doi: 10.1093/femsre/fuy044

Dhalla, F., Murray, S., Sadler, R., Chaigne-Delalande, B., Sadaoka, T., Soilleux, E., et al. (2015). Identification of a novel mutation in MAGT1 and progressive multifocal leucoencephalopathy in a 58-year-old man with XMEN disease. J. Clin. Immunol. 35, 112-118. doi: 10.1007/s10875-014-0116-2

Dittmer, D. P., and Damania, B. (2016). Kaposi sarcoma-associated herpesvirus: immunobiology, oncogenesis, and therapy. J. Clin. Invest. 126, 3165-3175. doi: 10.1172/JCI84418

Dunmire, S. K., Verghese, P. S., and Balfour, H. H.Jr. (2018). Primary Epstein-Barr virus infection. J. Clin. Virol. 102, 84-92. doi: 10.1016/j.jcv.2018.03.001

Ehlers, B., Spiess, K., Leendertz, F., Peeters, M., Boesch, C., Gatherer, D., et al. (2010). Lymphocryptovirus phylogeny and the origins of Epstein-Barr virus. J. Gen. Virol. 91, 630-642. doi: 10.1099/vir.0.017251-0

Faure, A., Hayes, M., and Sugden, B. (2019). How Kaposi's sarcoma-associated herpesvirus stably transforms peripheral B cells towards lymphomagenesis. Proc. Natl. Acad. Sci. U.S.A. 116, 16519-16528. doi: 10.1073/pnas.1905025116

Frohlich, J., and Grundhoff, A. (2020). Epigenetic control in Kaposi sarcomaassociated herpesvirus infection and associated disease. Semin. Immunopathol. 42, 143-157. doi: 10.1007/s00281-020-00787-z

Frost, T. C., and Gewurz, B. E. (2018). Epigenetic crossroads of the Epstein-Barr virus B-cell relationship. Curr. Opin. Virol. 32, 15-23. doi: 10.1016/ j.coviro.2018.08.012

Fullwood, R. A., Low, G. M., Chase, E. P., Grasley, M., Beal, S. S., McCrary, I. M., et al. (2018). The Kaposi's sarcoma-associated herpesvirus viral interleukin 6 gene affects metastasis and expression of B cell markers in a murine xenograft model. PloS One 13, e0204947. doi: 10.1371/journal.pone.0204947

Grisotto, M. G., Garin, A., Martin, A. P., Jensen, K. K., Chan, P., Sealfon, S. C., et al. (2006). The human herpesvirus 8 chemokine receptor vGPCR triggers autonomous proliferation of endothelial cells. J. Clin. Invest. 116, 1264-1273. doi: 10.1172/JCI26666

Guo, H. G., Sadowska, M., Reid, W., Tschachler, E., Hayward, G., and Reitz, M. (2003). Kaposi's sarcoma-like tumors in a human herpesvirus 8 ORF74 transgenic mouse. J. Virol. 77, 2631-2639. doi: 10.1128/JVI.77.4.2631-2639.2003

Gurer, C., Strowig, T., Brilot, F., Pack, M., Trumpfheller, C., Arrey, F., et al. (2008). Targeting the nuclear antigen 1 of Epstein-Barr virus to the human endocytic receptor DEC-205 stimulates protective T-cell responses. Blood 112, 12311239. doi: 10.1182/blood-2008-03-148072

Heller, K. N., Gurer, C., and Münz, C. (2006). Virus-specific CD4 $4^{+}$T cells: ready for direct attack. J. Exp. Med. 203, 805-808. doi: 10.1084/jem.20060215

Hendricks, D. W., Balfour, H. H.Jr., Dunmire, S. K., Schmeling, D. O., Hogquist, K. A., and Lanier, L. L. (2014). Cutting edge: NKG2C(hi)CD57+ NK cells respond specifically to acute infection with cytomegalovirus and not Epstein-Barr virus. J. Immunol. 192, 4492-4496. doi: 10.4049/jimmunol.1303211

Hjalgrim, H., Askling, J., Rostgaard, K., Hamilton-Dutoit, S., Frisch, M., Zhang, J. S., et al. (2003). Characteristics of Hodgkin's lymphoma after infectious mononucleosis. N. Engl. J. Med. 349, 1324-1332. doi: 10.1056/NEJMoa023141 
Hjalgrim, H., Smedby, K. E., Rostgaard, K., Molin, D., Hamilton-Dutoit, S., Chang, E. T., et al. (2007). Infectious mononucleosis, childhood social environment, and risk of Hodgkin lymphoma. Cancer Res. 67, 2382-2388. doi: 10.1158/00085472.CAN-06-3566

Hjalgrim, H., Rostgaard, K., Johnson, P. C., Lake, A., Shield, L., Little, A. M., et al. (2010). HLA-A alleles and infectious mononucleosis suggest a critical role for cytotoxic T-cell response in EBV-related Hodgkin lymphoma. Proc. Natl. Acad. Sci. U.S.A. 107, 6400-6405. doi: 10.1073/pnas.0915054107

Hochberg, D., Middeldorp, J. M., Catalina, M., Sullivan, J. L., Luzuriaga, K., and Thorley-Lawson, D. A. (2004). Demonstration of the Burkitt's lymphoma Epstein-Barr virus phenotype in dividing latently infected memory cells in vivo. Proc. Natl. Acad. Sci. U.S.A. 101, 239-244. doi: 10.1073/pnas.2237267100

Holst, P. J., Rosenkilde, M. M., Manfra, D., Chen, S. C., Wiekowski, M. T., Holst, B., et al. (2001). Tumorigenesis induced by the HHV8-encoded chemokine receptor requires ligand modulation of high constitutive activity. J. Clin. Invest. 108, 1789-1796. doi: 10.1172/JCI13622

Jensen, K. K., Manfra, D. J., Grisotto, M. G., Martin, A. P., Vassileva, G., Kelley, K., et al. (2005). The human herpes virus 8-encoded chemokine receptor is required for angioproliferation in a murine model of Kaposi's sarcoma. J. Immunol. 174, 3686-3694. doi: 10.4049/jimmunol.174.6.3686

Jochum, S., Moosmann, A., Lang, S., Hammerschmidt, W., and Zeidler, R. (2012). The EBV immunoevasins vIL-10 and BNLF2a protect newly infected B cells from immune recognition and elimination. PloS Pathog. 8, e1002704. doi: 10.1371/journal.ppat.1002704

Kanakry, J. A., Hegde, A. M., Durand, C. M., Massie, A. B., Greer, A. E., Ambinder, R. F., et al. (2016). The clinical significance of EBV DNA in the plasma and peripheral blood mononuclear cells of patients with or without EBV diseases. Blood 127, 2007-2017. doi: 10.1182/blood-2015-09-672030

Kanekiyo, M., Bu, W., Joyce, M. G., Meng, G., Whittle, J. R., Baxa, U., et al. (2015). Rational Design of an Epstein-Barr Virus Vaccine Targeting the ReceptorBinding Site. Cell 162, 1090-1100. doi: 10.1016/j.cell.2015.07.043

Kempkes, B., and Robertson, E. S. (2015). Epstein-Barr virus latency: current and future perspectives. Curr. Opin. Virol. 14, 138-144. doi: 10.1016/j.coviro.2015.09.007

Klein, U., Gloghini, A., Gaidano, G., Chadburn, A., Cesarman, E., Dalla-Favera, R., et al. (2003). Gene expression profile analysis of AIDS-related primary effusion lymphoma (PEL) suggests a plasmablastic derivation and identifies PELspecific transcripts. Blood 101, 4115-4121. doi: 10.1182/blood-2002-10-3090

Kulwichit, W., Edwards, R. H., Davenport, E. M., Baskar, J. F., Godfrey, V., and Raab-Traub, N. (1998). Expression of the Epstein-Barr virus latent membrane protein 1 induces B cell lymphoma in transgenic mice. Proc. Natl. Acad. Sci. U.S.A. 95, 11963-11968. doi: 10.1073/pnas.95.20.11963

Labo, N., Marshall, V., Miley, W., Davis, E., McCann, B., Stolka, K. B., et al. (2019). Mutual detection of Kaposi's sarcoma-associated herpesvirus and Epstein-Barr virus in blood and saliva of Cameroonians with and without Kaposi's sarcoma. Int. J. Cancer 145, 2468-2477. doi: 10.1002/ijc.32546

Landtwing, V., Raykova, A., Pezzino, G., Beziat, V., Marcenaro, E., Graf, C., et al. (2016). Cognate HLA absence in trans diminishes human NK cell education. J. Clin. Invest. 126, 3772-3782. doi: 10.1172/JCI86923

Latour, S., and Fischer, A. (2019). Signaling pathways involved in the T-cellmediated immunity against Epstein-Barr virus: Lessons from genetic diseases. Immunol. Rev. 291, 174-189. doi: 10.1111/imr.12791

Linnerbauer, S., Behrends, U., Adhikary, D., Witter, K., Bornkamm, G. W., and Mautner, J. (2014). Virus and autoantigen-specific $\mathrm{CD} 4^{+} \mathrm{T}$ cells are key effectors in a SCID mouse model of EBV-associated post-transplant lymphoproliferative disorders. PloS Pathog. 10, e1004068. doi: 10.1371/journal.ppat.1004068

Long, H. M., Meckiff, B. J., and Taylor, G. S. (2019). The T-cell Response to Epstein-Barr Virus-New Tricks From an Old Dog. Front. Immunol. 10, 2193. doi: $10.3389 /$ fimmu.2019.02193

Luzuriaga, K., and Sullivan, J. L. (2010). Infectious mononucleosis. N. Engl. J. Med. 362, 1993-2000. doi: 10.1056/NEJMcp1001116

Ma, S. D., Hegde, S., Young, K. H., Sullivan, R., Rajesh, D., Zhou, Y., et al. (2011). A new model of Epstein-Barr virus infection reveals an important role for early lytic viral protein expression in the development of lymphomas. J. Virol. 85, 165-177. doi: 10.1128/JVI.01512-10

Ma, S. D., Yu, X., Mertz, J. E., Gumperz, J. E., Reinheim, E., Zhou, Y., et al. (2012). An Epstein-Barr Virus (EBV) mutant with enhanced BZLF1 expression causes lymphomas with abortive lytic EBV infection in a humanized mouse model. J. Virol. 86, 7976-7987. doi: 10.1128/JVI.00770-12
Mariggio, G., Koch, S., and Schulz, T. F. (2017). Kaposi sarcoma herpesvirus pathogenesis. Philos. Trans. R. Soc. Lond. B. Biol. Sci. 372, 20160275. doi: 10.1098/rstb.2016.0275

McHugh, D., Caduff, N., Barros, M. H. M., Rämer, P., Raykova, A., Murer, A., et al. (2017). Persistent KSHV infection increases EBV-associated tumor formation in vivo via enhanced EBV lytic gene expression. Cell Host Microbe 22, 61-73. doi: 10.1016/j.chom.2017.06.009

Meixlsperger, S., Leung, C. S., Ramer, P. C., Pack, M., Vanoaica, L. D., Breton, G., et al. (2013). CD141 ${ }^{+}$dendritic cells produce prominent amounts of IFN-alpha after dsRNA recognition and can be targeted via DEC-205 in humanized mice. Blood 121, 5034-5044. doi: 10.1182/blood-2012-12-473413

Montaner, S., Sodhi, A., Molinolo, A., Bugge, T. H., Sawai, E. T., He, Y., et al. (2003). Endothelial infection with KSHV genes in vivo reveals that vGPCR initiates Kaposi's sarcomagenesis and can promote the tumorigenic potential of viral latent genes. Cancer Cell 3, 23-36. doi: 10.1016/S1535-6108(02)00237-4

Montaner, S., Sodhi, A., Servitja, J. M., Ramsdell, A. K., Barac, A., Sawai, E. T., et al. (2004). The small GTPase Racl links the Kaposi sarcoma-associated herpesvirus vGPCR to cytokine secretion and paracrine neoplasia. Blood 104, 2903-2911. doi: 10.1182/blood-2003-12-4436

Moutschen, M., Leonard, P., Sokal, E. M., Smets, F., Haumont, M., Mazzu, P., et al. (2007). Phase I/II studies to evaluate safety and immunogenicity of a recombinant gp350 Epstein-Barr virus vaccine in healthy adults. Vaccine 25, 4697-4705. doi: 10.1016/j.vaccine.2007.04.008

Münz, C. (2019). Latency and lytic replication in the oncogenesis of the Epstein Barr virus. Nat. Rev. Micobiol. 17, 691-700. doi: 10.1038/s41579-019-0249-7

Münz, C. (2020). Cytotoxicity in Epstein Barr virus specific immune control. Curr. Opin. Virol. 46, 1-8. doi: 10.1016/j.coviro.2020.07.011

Nador, R. G., Cesarman, E., Chadburn, A., Dawson, D. B., Ansari, M. Q., Sald, J., et al. (1996). Primary effusion lymphoma: a distinct clinicopathologic entity associated with the Kaposi's sarcoma-associated herpes virus. Blood 88, 645656. doi: 10.1182/blood.V88.2.645.bloodjournal882645

Okuno, Y., Murata, T., Sato, Y., Muramatsu, H., Ito, Y., Watanabe, T., et al. (2019). Defective Epstein-Barr virus in chronic active infection and haematological malignancy. Nat. Microbiol. 4, 404-413. doi: 10.1038/s41564-018-0334-0

Pappworth, I. Y., Wang, E. C., and Rowe, M. (2007). The switch from latent to productive infection in Epstein-Barr virus-infected B cells is associated with sensitization to NK cell killing. J. Virol. 81, 474-482. doi: 10.1128/JVI.01777-06

Parkin, D. M. (2006). The global health burden of infection-associated cancers in the year 2002. Int. J. Cancer 118, 3030-3044. doi: 10.1002/ijc.21731

Patiroglu, T., Haluk Akar, H., Gilmour, K., Unal, E., Akif Ozdemir, M., Bibi, S., et al. (2015). A case of XMEN syndrome presented with severe auto-immune disorders mimicking autoimmune lymphoproliferative disease. Clin. Immunol. 159, 58-62. doi: 10.1016/j.clim.2015.04.015

Pich, D., Mrozek-Gorska, P., Bouvet, M., Sugimoto, A., Akidil, E., Grundhoff, A., et al. (2019). First Days in the Life of Naive Human B Lymphocytes Infected with Epstein-Barr Virus. MBio 10, e01723-e01719. doi: 10.1128/mBio.01723-19

Prakash, O., Tang, Z. Y., He, Y. E., Ali, M. S., Coleman, R., Gill, J., et al. (2000). Human Kaposi's sarcoma cell-mediated tumorigenesis in human immunodeficiency type 1 tat-expressing transgenic mice. J. Natl. Cancer Inst. 92, 721-728. doi: 10.1093/jnci/92.9.721

Prakash, O., Tang, Z. Y., Peng, X., Coleman, R., Gill, J., Farr, G., et al. (2002). Tumorigenesis and aberrant signaling in transgenic mice expressing the human herpesvirus-8 K1 gene. J. Natl. Cancer Inst. 94, 926-935. doi: 10.1093/jnci/94.12.926

Prakash, O., Swamy, O. R., Peng, X., Tang, Z. Y., Li, L., Larson, J. E., et al. (2005). Activation of Src kinase Lyn by the Kaposi sarcoma-associated herpesvirus K1 protein: implications for lymphomagenesis. Blood 105, 3987-3994. doi: 10.1182/blood-2004-07-2781

Ravell, J. C., Matsuda-Lennikov, M., Chauvin, S. D., Zou, J., Biancalana, M., Deeb, S. J., et al. (2020a). Defective glycosylation and multisystem abnormalities characterize the primary immunodeficiency XMEN disease. J. Clin. Invest. 130, 507-522. doi: 10.1172/JCI131116

Ravell, J. C., Chauvin, S. D., He, T., and Lenardo, M. (2020b). An Update on XMEN Disease. J. Clin. Immunol. 40, 671-681. doi: 10.1007/s10875-020-00790-x

Robey, R. C., Mletzko, S., and Gotch, F. M. (2010). The T-Cell Immune Response against Kaposi's Sarcoma-Associated Herpesvirus. Adv. Virol. 2010, 340356. doi: 10.1155/2010/340356

Rosean, T. R., Holman, C. J., Tompkins, V. S., Jing, X., Krasowski, M. D., RoseJohn, S., et al. (2016). KSHV-encoded vIL-6 collaborates with deregulated c- 
Myc to drive plasmablastic neoplasms in mice. Blood Cancer J. 6, e398. doi: 10.1038/bcj.2016.6

Roshan, R., Labo, N., Trivett, M., Miley, W., Marshall, V., Coren, L., et al. (2017). T-cell responses to KSHV infection: a systematic approach. Oncotarget 8, 109402-109416. doi: 10.18632/oncotarget.22683

Rühl, J., Citterio, C., Engelmann, C., Haigh, T. A., Dzionek, A., Dreyer, J. H., et al. (2019). Heterologous prime-boost vaccination protects from EBV antigen expressing lymphomas. J. Clin. Invest. 129, 2071-2087. doi: 10.1172/JCI125364

Rühl, J., Leung, C. S., and Münz, C. (2020). Vaccination against the Epstein-Barr virus. Cell Mol. Life Sci. 77, 4315-4324. doi: 10.1007/s00018-020-03538-3

Ruiss, R., Jochum, S., Wanner, G., Reisbach, G., Hammerschmidt, W., and Zeidler, R. (2011). A virus-like particle-based Epstein-Barr virus vaccine. J. Virol. 85, 13105-13113. doi: 10.1128/JVI.05598-11

Sallah, N., Miley, W., Labo, N., Carstensen, T., Fatumo, S., Gurdasani, D., et al. (2020). Distinct genetic architectures and environmental factors associate with host response to the gamma2-herpesvirus infections. Nat. Commun. 11, 3849. doi: 10.1038/s41467-020-17696-2

Shannon-Lowe, C., and Rickinson, A. (2019). The Global Landscape of EBVAssociated Tumors. Front. Oncol. 9, 713. doi: 10.3389/fonc.2019.00713

Sin, S. H., and Dittmer, D. P. (2013). Viral latency locus augments B-cell response in vivo to induce chronic marginal zone enlargement, plasma cell hyperplasia, and lymphoma. Blood 121, 2952-2963. doi: 10.1182/blood-2012-03-415620

Sin, S. H., Kim, Y., Eason, A., and Dittmer, D. P. (2015). KSHV Latency Locus Cooperates with Myc to Drive Lymphoma in Mice. PloS Pathog. 11, e1005135. doi: 10.1371/journal.ppat.1005135

Smith, C., Cooper, L., Burgess, M., Rist, M., Webb, N., Lambley, E., et al. (2006). Functional reversion of antigen-specific $\mathrm{CD} 8^{+} \mathrm{T}$ cells from patients with Hodgkin lymphoma following in vitro stimulation with recombinant polyepitope. J. Immunol. 177, 4897-4906. doi: 10.4049/jimmunol.177.7.4897

Strowig, T., Chijioke, O., Carrega, P., Arrey, F., Meixlsperger, S., Ramer, P. C., et al. (2010). Human NK cells of mice with reconstituted human immune system components require preactivation to acquire functional competence. Blood 116, 4158-4167. doi: 10.1182/blood-2010-02-270678

Suthaus, J., Stuhlmann-Laeisz, C., Tompkins, V. S., Rosean, T. R., Klapper, W., Tosato, G., et al. (2012). HHV-8-encoded viral IL-6 collaborates with mouse IL-6 in the development of multicentric Castleman disease in mice. Blood 119, 5173-5181. doi: 10.1182/blood-2011-09-377705

Tangye, S. G., and Latour, S. (2020). Primary immunodeficiencies reveal the molecular requirements for effective host defense against EBV infection. Blood 135, 644-655. doi: 10.1182/blood.2019000928
Taylor, G. S., Haigh, T. A., Gudgeon, N. H., Phelps, R. J., Lee, S. P., Steven, N. M. et al. (2004). Dual stimulation of Epstein-Barr Virus (EBV)-specific CD4 $4^{+}$-and $\mathrm{CD} 8^{+}$-T-cell responses by a chimeric antigen construct: potential therapeutic vaccine for EBV-positive nasopharyngeal carcinoma. J. Virol. 78, 768-778. doi: 10.1128/JVI.78.2.768-778.2004

Taylor, G. S., Long, H. M., Brooks, J. M., Rickinson, A. B., and Hislop, A. D. (2015). The immunology of Epstein-Barr virus-induced disease. Annu. Rev. Immunol. 33, 787-821. doi: 10.1146/annurev-immunol-032414-112326

Thorley-Lawson, D. A. (2001). Epstein-Barr virus: exploiting the immune system. Nat. Rev. Immunol. 1, 75-82. doi: 10.1038/35095584

van Zyl, D. G., Tsai, M. H., Shumilov, A., Schneidt, V., Poirey, R., Schlehe, B., et al. (2018). Immunogenic particles with a broad antigenic spectrum stimulate cytolytic $\mathrm{T}$ cells and offer increased protection against EBV infection ex vivo and in mice. PloS Pathog. 14, e1007464. doi: 10.1371/journal.ppat.1007464

Walens, A., DiMarco, A. V., Lupo, R., Kroger, B. R., Damrauer, J. S., and Alvarez, J. V. (2019). CCL5 promotes breast cancer recurrence through macrophage recruitment in residual tumors. Elife 8, e43653. doi: 10.7554/ eLife.43653

Wang, S., Wang, S., Maeng, H., Young, D. P., Prakash, O., Fayad, L. E., et al. (2007). K1 protein of human herpesvirus 8 suppresses lymphoma cell Fas-mediated apoptosis. Blood 109, 2174-2182. doi: 10.1182/blood-2006-02-003178

Williams, H., McAulay, K., Macsween, K. F., Gallacher, N. J., Higgins, C. D., Harrison, N., et al. (2005). The immune response to primary EBV infection: a role for natural killer cells. Br. J. Haematol. 129, 266-274. doi: 10.1111/j.13652141.2005.05452.x

Yang, T. Y., Chen, S. C., Leach, M. W., Manfra, D., Homey, B., Wiekowski, M., et al. (2000). Transgenic expression of the chemokine receptor encoded by human herpesvirus 8 induces an angioproliferative disease resembling Kaposi's sarcoma. J. Exp. Med. 191, 445-454. doi: 10.1084/jem.191.3.445

Conflict of Interest: The author declares that the research was conducted in the absence of any commercial or financial relationships that could be construed as a potential conflict of interest.

Copyright $\odot 2021$ Münz. This is an open-access article distributed under the terms of the Creative Commons Attribution License (CC BY). The use, distribution or reproduction in other forums is permitted, provided the original author(s) and the copyright owner(s) are credited and that the original publication in this journal is cited, in accordance with accepted academic practice. No use, distribution or reproduction is permitted which does not comply with these terms. 